\title{
ROCHAS VULCÂNICAS DO GRUPO SÃO ROQUE, NA REGIÃO DO MORRO BOTURUNA EM SÃO PAULO
}

M.Bergmann

I.McReath

Em perfis efetuados na vertente $\mathbf{N}$ do Morro Boturuna, próximo a Pirapora do Bom Jesus, são observados numerosos corpos tabulares de rochas vulcânicas a sub-vulcânicas, intercalados a metarcóseos com padrão de deformação politásico e de grau metamórfico fácies xistos verdes.

O pacote de metarenitos arcoseanos com matriz constitui uma unidade clástica alóctone do Grupo São Roque na região, representando ambiente de águas relativamente rasas, em contraste à unidade clástica turbidftica sobre a qual assenta-se por contato tectônico.

$\mathrm{Na}$ extremidade E do Morro Boturuna são observados ao menos 8 intercalações vulcânicas a sub-vulcânicas, uma delas discordante do acamamento dos metarcóseos, conformando um dique de $1,5 \mathrm{~m}$ de espessura.

A partir da base do pacote alóctone, as primeiras intercalações são submétricas, têm amigdalas esparsas, e balizam um nivel estratigráfico bastante contínuo ao longo do Morro Boturuna.

Este nivel corresponde a metarenitos arcoseanos médios com matriz sericitica entre 15 e 30\%, e grãos de quartzo, microclínio e plagioclásio com contornos arredondados ou preservados.

As rochas são laminadas a bandadas, em ritmos ou granodecrescentes e têm caracteristicas estratificações cruzadas tabulares de ângulo médio, em "sets" decimétricos localmente observáveis.

Departamento de Geologia Geral, Instituto de Geociências, USP. 
Os contatos inferiores das rochas vulcânicas e metarcóseos são bruscos, planoparalelos ou irregulares e falhados. Quase sempre a estratificação dos psamitos é concordante aos bancos vulcânicos e à sua estruturação interna, como distribuição de zonas de amígdalas ou variação no tamanho e deformação das mesmas.

Já os contatos superiores são muitas vezes gradacionais ao longo de poucos decimetros, através de rochas com aspecto de metarcóseos ricos em matriz ou de rochas sericiticas a ilmenita.

São também frequentes nos contatos veios de quartzo hialino e leitoso, de pequena possança, que partem da rocha vulcânica e alojam-se nos metarcóseos. Na parte média do pacote, a meia encosta da elevação, situa-se o corpo mais possante dos vulcanitos, de espessura aparente inferior a 20m. Al foi obtida a maioria das amostras frescas próprias para laminação, bem como um conjunto de 4 amostras analisadas quimicamente. A rocha fresca ou semi-fresca tem cor cinzaazulada, granulação fina e aspecto de filito, exceto por amígdalas quartzosas de $1 \mathrm{~cm}$ e menores, esparsas.

As intercalações superiores têm espessura em torno de $2-3 m$ e são francamente amigdalóides, com zonas decimétricas ricas em amígdalas quartzosas, recorrentes dentro dos bancos vulcânicos. As amígdalas têm tamanhos entre $1,5 \mathrm{~cm}$ e poucos milimetros, e ocorrem quase indeformadas ou com estiramento extremo, as primeiras na base de cada zona amigdalóide, e com deformação gradativa em direção ao topo. A distribuição de tamanhos é também por vezes gradativa (tamanhos menores) da base para o topo dos niveis, assim como podem ocorrer passagens graduais entre as porções mais ou menos vesiculadas.

As últimas intercalações observadas não são amigdalóides, e dão-se em psamitos com estratificações cruzadas de baixo ângulo, bancos submétricos com laminação hematf́tica e intraclastos destas mesmas lâminas, caracterizando um possivel ambiente de praia.

Petrograficamente, as rochas metavulcânicas finas apresentam sericita (70\%), ilmenita (até 15\%) e quartzo, apatita, epidoto e magnetita como acessórios. As amígdalas são preenchidas por quartzo em cristais límpidos de contorno poligonal ou em cristais de contorno decussado, com inclusões de palhetas e massas de sericita. Vestígios de feldspato podem ser sugeridos pela forma das massas sericiticas em algumas amígdalas, e talvez na matriz da rocha. A foliação $\left(\mathrm{S}_{2}\right)$ é conferida pelo alinhamento das sericitas e das ripas de opacos. Tanto as últimas como as amigdalas estão ligeiramente rotacionadas na foliação, e apresentam sombras de pressão.

Foi encontrada também uma rocha porfiróide fina, com glomérulos, rosetas e fenocristais isolados de plagioclásio, em ripas orientadas de 1-2mm, em matriz fina. O plagioclásio 
perfaz 65\% da rocha, e os demais constituintes são minerais opacos limonitizados com textura esquelética (20-25\%) e sericita, epidoto, titanita e zircão como acessórios.

Análises químicas para os elementos maiores e alguns elementos traços não revelaram composições ígneas para as rochas vulcânicas, caracterizadas por teores de $\mathrm{Al}_{2} \mathrm{O}_{3}$ de cerca de $20 \%$, razões $\mathrm{K}_{2} \mathrm{O} /\left(\mathrm{K}_{2} \mathrm{O}+\mathrm{Na}_{2} \mathrm{O}\right.$ ) (\% de óxidos) de cerca 1.0 e ferro muito oxidado. Tais composições podem resultar de modificações hidrotermais da rocha original, ou até de intemperismo forte.

Os metarcóseos com niveis vulcânicos a sub-vulcânicos do Morro Boturuna podem ser correlacionados ao pacote descrito algumas dezenas de $\mathrm{km} \mathrm{a} \mathrm{E}$, como metapsamitos impuros com intercalações de "rochas metavulcânicas básicas amigdaloidais", e "meta-subvulcânicas riodacíticas" como a ocorrência do Morro do Polvilho. Neste local a curva concórdia para zircões e uma isócrona $\mathrm{Rb} / \mathrm{Sr}$ em rocha total indicam idades próximas a $1800 \mathrm{Ma}$. Amostras de alteritos das rochas vulcânicas de Boturuna foram tratadas para a separação de zircões, não se obtendo resultados. 